UDC 811.111'36:811.161.2'36

DOI 10.35433/philology.1(89).2019.11-18
I. D. Karamysheva,

Candidate of Philological Sciences, Associate Professor

(Lviv Polytechnic National University)

iryn ka@ukr.net

ORCID: $0000-000 \overline{1}-8683-2040$

\title{
TERTIUM COMPARATIONIS IN MODERN CONTRASTIVE LINGUISTICS (REVISING APPROACHES TO TEACHING)
}

The article focuses on the main debatable issues in the field of cross-cultural language studies. The place of modern Contrastive Linguistics among related disciplines such as Comparative-Historic Linguistics, Areal Linguistics, Typological Linguistics is described. The scheme providing the subdivisions of Comparative Linguistics (according to prof. Nadiya Andreichuk), showing the place of modern Contrastive Linguistics and taking into account synchronic and diachronic as well as theoretical and applied aspects of contrastive language studies, is presented. There are highlighted periods of development of contrastive studies that influenced the principles and terminology apparatus, worked out in theoretical and applied contrastive studies. Briefly the periods of early contrastive studies as well as the traditional period of contrastive ideas development (the end of 19th century until after World War II) are mentioned. More attention is paid to pedagogically oriented contrastive studies during the Classical period of CL development (1945-1965) up to modern period in the history of CL, especially in Ukraine. Some of the main theoretical reasonings applied by Ukrainian researchers (among them Yu. O. Zhluktenko, M. P. Kocherhan, I. V. Korunets, A. E. Levytsky, N. I. Andreichuk) in published by them teaching manuals and textbooks are described, which create the necessary didactic background for acquiring both theoretical and methodological foundations on which modern Contrastive Linguistics is grounded. Approaches towards understanding and appropriate usage of tertium comparationis as a common platform for comparison are discussed, which enables a correct analysis of the research object in order to reveal its common and distinctive features in contrasted languages.

Key words: contrastive linguistics, contrastive analysis, platform for comparison, tetium comparationis, comparability criterion, equivalence.

"One of the reasons why contrastive studies continue to perform the role of the Cinderella of linguistics is the fact that its most fundamental concept tertium comparationis remains as hazy as ever". (Tomasz P. Krzeszowski "Contrasting Languages. The Scope of Contrastive Linguistics", 1990 [1: 15])

Introduction. Modern Contrastive Linguistics (CL) enlarges the sphere of its usage which is connected with the growing role of cross-cultural communication in all its manifestations. To provide a better efficiency of teaching foreign languages alongside with the theory and practice of translation higher educational establishments develop specialized courses of contrastive language studies aimed at familiarizing of future professionals in the spheres of translation, cross-cultural communication, applied linguistics with fundamentals of contrastive analysis and its application to the research of lexical, grammatical, stylistic, pragmatic etc. peculiarities of lingual objects.

Teaching disciplines belonging to the contrastive cycle (especially lexicology, grammar and stylistics) should be naturally provided with the appropriate methodological materials as well as teaching manuals and textbooks. Thus, highlighting the present stage of this process causes the topicality of this research. Its aim being to reveal alongside the theoretical issues of modern contrastive language studies which are still disputable from researcher to researcher. These main issues to be discussed and exemplified are: 1) the place of CL among other disciplines dealing with ideas of languages contrast and comparison; 2) the methodological basis of research, in particular the correct application and understanding of the nature of "tertium comparationis" notion.

Problem Setting. Every human language can be characterized by three types of features: universal, typological and individual found only in this particular language. The mentioned features can be revealed only by means of employing contrasting or comparison. Comparison or contrasting as a method is not a new one and is used by a number of linguistic disciplines, namely: areal linguistics, studying languages of a particular geographic area despite their genetic relations and with respect to their mutual influence of one language upon another; comparative-historic linguistics, revealing the genetic kinship of languages from the diachronic point of view; typological linguistics, comparing similarities and differences within languages as well as classifying and referring languages accordingly to certain types; and, finally, contrastive linguistics (CL). CL, as a matter of fact, is still searching for its place within the system of linguistic disciplines and its belonging either to special or general linguistics, diachronic or synchronic one 
continues to be the source of debates among researchers. Therefore, it seems expedient to clarify intersections and relations of CL with the above mentioned linguistic disciplines before defining its status. The correlation between CL and comparative-historic linguistics lies in comparison of languages. Still the aim of such comparison is different. Similarly, areal linguistics, unlike CL, has as its task to define the areas of language interaction, to characterize the territorial division of language peculiarities, to research the processes of language convergence that is to give the territorial characteristics of language peculiarities dealing with the idea of comparison as well. Contrasting and comparison are employed by both contrastive typology and contrastive linguistics [2: 15-16]. Therefore, it is worth considering some of the stages of CL development accompanied by appearance of research works, highlighting major advances of certain theoretical achievements in this sphere, to try and see the clear-cut difference between the mentioned disciplines [3: 30-31].

Analysis Procedure. CL (confrontative and comparative linguistics are often used as synonymic terms) as a language discipline, as it is traditionally believed, grew out of studies aimed at typological classification of languages in the middle of the 20th century and has been continuously developing since 50 -ies of the 20th century. But as the outstanding representative of the Polish school of CL Thomash Krzeszowski considers it is probable that comparisons of languages for pedagogical purposes go to the very beginning of foreign language teaching whereas systematic written records of such procedures go back to at least the 15 th century [4; 5: 49]. Further it is worth differentiating the so called traditional period of contrastive ideas development (the end of 19th century until after World War II), enriched by the ideas of Benjamin Lee Whorf and the Prague Linguistic Circle [5: 48]. It was the American linguist Benjamin Lee Whorf (1897-1941) who initiated classical contrastive studies and in his article "Language and Logic" (first published in 1941) used the term contrastive linguistics for denoting a comparative study which focuses on linguistic differences. Moreover, B. L. Whorf distinguished between comparative and contrastive linguistics. The linguist stated that contrastive linguistics is "of even greater importance for the future technology of thought" and he defines it as a discipline which "plots the outstanding differences among tongues - in grammar, logic, and general analysis of experience" [6;5:53]. Vilěm Mathesius, the founder of the Prague Linguistic Circle, saw as a ground for comparative analysis largely the study of the ways in which "common grammatical functions are expressed. Such a functional approach to contrastive research provides objectivity of the highest possible degree while dealing with language research. The communicative needs can be seen as largely identical in the communities using languages under comparison, thus we can treat them as a safe background against which the characteristic differences of the compared languages will clearly stand out [5:60]. Nevertheless, it has to be stated that research works of Ukrainian and Russian philologists (the end of the 19th - the beg. of the 20th centuries) can also be viewed as worthy samples of contrastive language studies, though, of course, being closer to typological studies. Here, first of all, the works by O. O. Potebnya, Boduen de Courtene, L.V. Shcherba should be mentioned.

The Classical period of CL development (1945-1965) is marked by pedagogically-oriented contrastive studies which began after the II World War with the increasing interest to teaching foreign languages in the USA [5: 101]. At those times huge funds were granted to cross-linguistic research, grounded on comparison, yielding valuable results for the methodology of foreign language teaching (in the USA in particular). Such initiatives followed the statement of Charles C. Fries who declared that: "the most efficient materials are those that are based upon a scientific description of the language to be learned, carefully compared with a parallel description of the native language of the learner" [7: 9]. Nevertheless, the classical period of CL development is associated largely with the name of his pupil Robert Lado who in 1957 published his work "Linguistics across Cultures" [8]. Quite often it is Robert Lados book that is considered to be the initial point of modern applied contrastive linguistics as it is understood both in American and European traditions. Establishing of CL as a separate discipline in the realm of comparative studies of languages was caused by holding conferences dedicated to contrastive cross-language studies (the first one was initiated in George-town, the USA, in 1968). Since the year 1972 CL topical issues were included into programs of numerous international linguistic congresses [3:34].

The term contrastive linguistics, being used to refer to language acquisition, changed later in a tradition of foreign schools to contrastive analysis (CA). CA, in its simplest variant, was grounded on the belief that the study of similarities and differences alone could be applied to solve the problem of learning difficulties' prediction. In case two languages were similar, positive transfer would occur; if they were different, negative transfer, or interference, would be witnessed. Quantity statistics shows that the biggest part of research works of this period is devoted to contrastive grammar (including word formation), the smaller number is devoted to contrastive phonology, and yet smaller number - to researches in contrastive lexicology.

CL of the second half of the 20th century, especially contrastive grammar research, was enriched by works of one more outstanding scholar - Ukrainian linguist Yuriy Oleksiyovych Zhluktenko (1915-1990) Here the study manual "A Comparative Grammar of English and Ukrainian Languages" (published in 1960) 
[9] is to be mentioned in the first place. He is also the author of many theoretical ideas within the CL field $[10 ; 11 ; 12]$ and the co-author of a series of contrastive analysis works of English, German, Russian and Ukrainian languages, e.g. [13]. Yu. O. Zhluktenko can rightly be considered the initiator of $\mathrm{CL}$ development in Ukrainian linguistics.

Modern period in Ukrainian contrastive language studies is truly marked by such an important work, presenting the contrastive typological research, as "Contrastive Typology of the English and Ukrainian languages" by the prominent Ukrainian linguist Ilko Vakulovych Korunets' (published in 2003) [14]. Since a lot of works, dealing with language comparison and contrasting, tend to be typologically oriented, it is apparent that the position of CL among other adjacent linguistic disciplines still needs to be précised.

Another outstanding Ukrainian scholar Mykhaylo Petrovych Kocherhan also regards this issue worth paying attention to and presents his understanding of CL (considering "confrontative linguistics" as a synonymic term) as a branch of linguistics studying two or more languages irrespective of their kinship with the aim of revealing their similarities and differences on all levels of the language structure (phonological, morphological, syntactic, lexical-semantic). It should be noticed that in his definition the researcher uses the following Ukrainian terms: зіставне мовознавство (контрастивна лінгвістика, конфронтативна лінгвістика) [2: 9]. His textbook "Fundamentals of Contrastive Linguistics" ("Основи зіставного мовознавства") published in 2006 [2] highlights such issues of CL as: problems of generally theoretical character; contrastive phonetics and phonology; contrastive derivatology and grammar; contrastive lexicology and phraseology.

Professor A. E. Levytsky, another prominent linguist, in his recently published "Comparative Grammar of English and Ukrainian languages" (2008) understands the object of Comparative Linguistics as a comparison of two or more language systems at the synchronic stage. Moreover, the overall target of Comparative Linguistics, according to researcher (preferring the term "Comparative Linguistics" to "Contrastive Linguistics"), is to define the most vital convergences and divergences in the languages of the world, with the aim of their classification, systematization and, as a result, developing recommendations for mastering a language in the process of its acquisition [15: 8-9].

Contrastive research is largely connected with the synchronic aspect of language study though some scholars believe that languages sometimes should be contrasted in diachrony, complementing the synchronic approach for particular research needs. Concerning the subject matter and tasks of CL there can be distinguished two points of view: one treats this discipline as a "purely" linguistic theory, tightly connected with typology (K. James) [16], the other points to the narrow practical application of contrastive researches, targeted to serve the needs of foreign languages study (G. Nickel) [17]. Foreign linguistics considers CL as a merely auxiliary discipline, serving the needs of the methodology of language teaching (W. Nemser) [18]. As a second rate or auxiliary one CL is also considered by those scholars who see the main objective of CL in revealing cross-cultural language similarities and differences as a further basis for typological generalizations. Such an approach diminishes CL status and limits its tasks, attaching a merely practical character to it. Studying this problem M. P. Kocherhan agrees in his conclusions with the scholar K. James who claims that CL includes features of both purely theoretical and practical or applied linguistics $[2 ; 16]$. The synchronic-comparative method or contrastive/confrontative method (M.P. Kocherhan considers these terms as synonyms in Ukrainian: контрастивний аналіз, синхроннопорівняльний метод, оr конфронтативний, зіставний, зіставно-типологічний аналіз etc.) gives the possibility to single out CL as a separate linguistic branch. M. P. Kocherhan also believes that CL should embrace both theoretical and practical tasks (consider in more details [2: 14]).

The dispute concerning the place of CL among adjacent disciplines, as well as the usage of appropriate terminology, seems to be solved in the work presented by Ukrainian professor Nadiya Ivanivna Andreichuk ("Contrastive Linguistics", Lviv, 2015). Nadiya Andreychuk is professor of Hryhoriy Kochur Department of Translation Studies and Contrastive Linguistics of Lviv National Ivan Franko University who in her time established the department of Applied Linguistics at Lviv Polytechnic National University, introducing into the study curriculum the block of contrastive disciplines, namely: Contrastive Lexicology, Contrastive Grammar, and Contrastive Stylistics of English and Ukrainian languages. Thus, her manual "Contrastive Linguistics" reflects the results of her theoretical and practical achievements, aptly leveraging the theoretical and practically-oriented nature of modern Contrastive Linguistics. Nadiya Andreichuk differentiates the terms "comparative" and "contrastive" linguistics and believes that "today comparative linguistics is a ramified field of research (Fig.1) with lots of subdivisions [5:20-21]: 


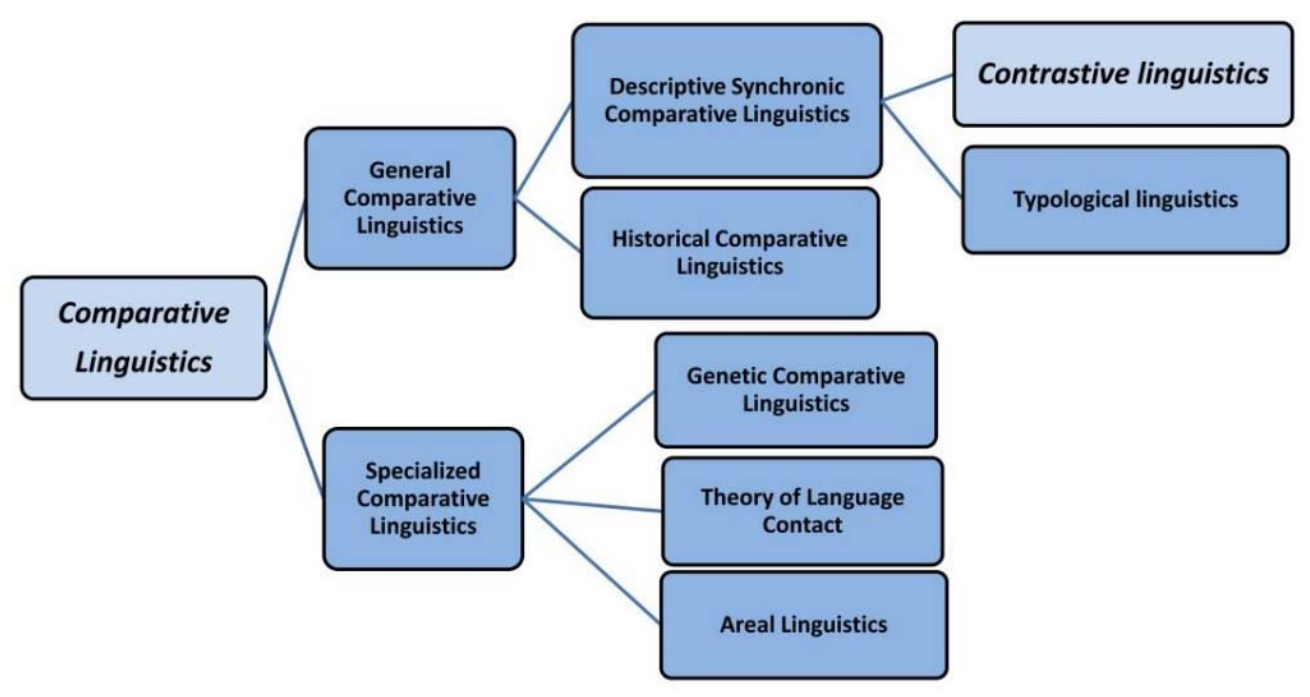

Figure 1. Subdivisions of Comparative Linguistics (according to prof. Nadiya Andreichuk)

Her understanding of $\mathrm{CL}$ is the following: "Contrastive linguistics is a particular linguistic enterprise within the field of descriptive synchronic comparative linguistics aimed at producing description of one language from the perspective of another and concerned with in depth analysis of similarities and contrasts that hold between them" [5: 34].

It is quite natural that $\mathrm{CL}$ uses the methods of its own. The main one is the method of contrastive analysis (CA) directed, first of all, towards revealing differences between two or larger number of languages (the unique features) though it does not neglect similar features of contrasted languages. The effectiveness of CA usage depends on what is contrasted and how it is contrasted. The researcher R. Shternemann [19] differentiates between one-sided and two-sided (many-sided) CA directions. One-sided approach carries out the crosslanguage comparison in the direction "the initial language or the source language - the target language". The two-sided (or many-sided) approach chooses as the basis for comparison the "third member" (tertium comparationis) - a certain extra-linguistic notion, a phenomenon which is not found in any of contrasted languages but is formed by a meta-language by means of deduction. Therefore we research the ways and means by which it is expressed in languages being contrasted. According to M. P. Kocherhan both approaches have their advantages and disadvantages and the differentiation between one-sided and two-sided approaches reminds the difference between semasiologic (lingual objects are considered from the form to their content) and onomasiologic (lingual objects are studied in the direction from the content to their form) approaches [2: 80-81].

The effectiveness of contrastive analysis, as M. P. Kocherhan further argues, is connected with a correctly chosen etalon (also the common denominator, the basis for comparison,) which helps to define the way a certain characteristic feature is expressed or manifested. Therefore, it is believed by many researchers that for this purpose a special meta-language should be used. Meta-language, as a rule, embodies a certain ideal language system, being applied as an instrument for comparison of real language systems. Tertium comparationis ("третій член порівняння", "мова-еталон" оr "основа зіставлення") is often used as a synonymic term in the meaning of "language-etalon". The mentioned terms are wider since they embrace not only a natural or an artificially created language, but also more concrete, narrower objects as a basis for comparison. These can be, for instance, some notional categories (definiteness, modality, causality, possessivity, predicativity, etc.). Quite often and not quite accurately they are termed as "language-etalon" whereas in reality they are merely the platform for comparison, the third member, the notion on the basis of which one can observe the way they are expressed in contrasted languages. The terms "basis for comparison" or "tertium comparationis" should be preferable in such cases. Examples of tertium comparationis in language contrasting can be the following: any specific concepts (using the notions of modern cognitive linguistics); propositions (regarded by traditional semantics as invariants common for all the members of modal and communicative paradigms of sentences as well as their derivative constructions); models of coherent texts or communicative situations; social, gender, age, as well as situational correlation of a communicative act participants, taking into account ethnic-cultural peculiarities of contrasted languages. Consequently, one can use various means as a basis for comparison: a symbolic language, consisting of general artificial rules or a specifically constructed artificial language; a certain language with a welldeveloped system; a certain system; some linguistic (semantic, grammatical, etc.) category; any differential characteristics; a certain semantic field; a certain grammatical rule; phonetic, morphological, syntactic and other types of models; a certain method; a typological category; an interlingua by translation, etc. [2: 84-85].

Proceeding with the idea of laying the basis for the correct contrastive analysis in the teaching process we totally agree with the idea grounded by N. I. Andreichuk that "comparability criterion is one of the key concepts 
and has to be established prior to any analysis" [5: 195]. The linguist dealing with CA is expected to answer questions: what lingual objects can be compared in the chosen for research languages and what the aspects of comparison are. Therefore, N. I. Andreichuk proposes to use three approaches in theoretical contrastive studies:

1) small systems of lingual features of a lingual object are contrasted;

2) semantic, syntactic, word-formation, rhetoric and other fields are compared;

3) preferences in choosing different aspects underlying processes of lingual objects' creating [5: 195].

Different tertia comparationis can be applied within these approaches (Fig. 2.):

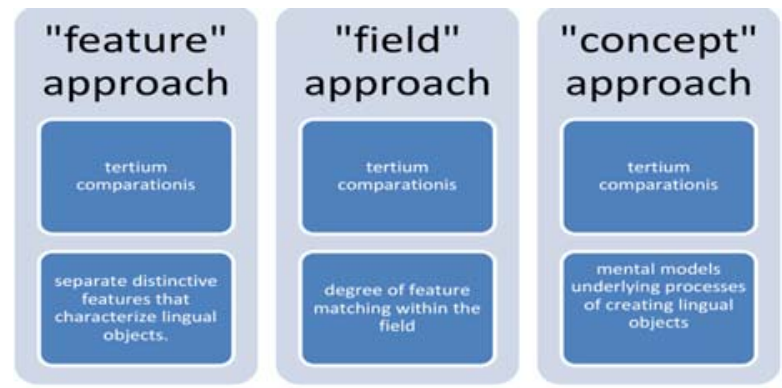

Figure 2. Tertia comparationis applied within three main approaches in contrastive studies (by prof. Nadiya Andreichuk).

There are three main approaches that are traditionally distinguished while dealing with the problem of comparability, as N. I. Andreichuk further argues. Originally, researchers tried to establish it either at the semantic (the first approach) or formal/grammatical level (the second approach). The third approach of establishing comparability criterion implies determining the relations of equivalence, similarity and difference in the languages compared. The notion of equivalence was formerly borrowed from theory of translation and it comprised the concept of translation equivalence. Equivalence in contrastive studies, more specifically, presupposes that there is some universal feature, an overall platform of reference, tertium comparationis, which enables the comparison to be carried out [5: 196]. The researcher dealing with languages' contrasting should be interested in the factual realization of this universal feature in languages being studied. Andrew Chesterman, expert in Translation Studies, believes that tertium comparationis, allowing the comparison to be performed, is, in other words, a background of samness, and the sine qua non (an essential or indispensable element, condition or ingredient) for any justifiable systematic study of contrasts [20: 163]. Consequently, the main question to be answered by a researcher is: which categories can be used to compare languages.

Sample of Contrastive Analysis Application. It seems expedient to show the application of tertium comparationis by using some concrete examples. It is necessary to show to students that the choice of tertium comparationis is predetermined by the nature of object studied as well as the aim of our research. If, for example, the object is the noun, and the main objective is to establish similar and different features of it as a part of speech, then tertia comparationis are the ahead predetermined scope of features which can characterize this part of speech.

In the textbook "Contrastive Grammar of English and Ukrainian Languages", $3^{\text {rd }}$ revised edition, Lviv, 2017 [3] $\left(1^{\text {st }}\right.$ edition 2008, $2^{\text {nd }}$ revised edition 2012) the scope of features, comprising the notion of "a part of speech", are used a basis or platform for providing contrastive grammatical analysis of parts of speech in both mentioned languages.

A part of speech is a class of lexemes characterized by:

1) its lexico-grammatical meaning,

2) its lexico-grammatical morphemes (stem-building elements),

3) its grammatical categories or its paradigms,

4) its combinability, and 5) its functions in a sentence [3: 51].

Therefore, it is worth presenting the contrastive analysis of noun as a part of speech using five features mentioned above used as tertia comparationis.

Noun as a part of speech in English and Ukrainian languages contains the following features:

1. The lexico-grammatical meaning that of "substantivity" which is similar in both languages.

2. Typical stem-building morphemes.

In the English language: program-ist, teach-er, friend-ship, develop-ment, etc.

The Ukrainian noun possesses a much greater variety of lexico-grammatical morphemes in comparison with its English counterpart. The peculiarity of Ukrainian is also the wealth of "subjective appraisal" (diminutive) suffixes, as in хлопчатко, котик, моріжечок, etc. According to I.V. Korunets', the number of diminutive only noun forming suffixes is as many as 53 which goes in no comparison with the English 14 suffixes [14: 149]. Totally missing in English but existing in Ukrainian are augmentative suffuixes, for example: -ил (барило), -иш, (дубище), -ук/-юк (зміюка), -уг /-юг (злодюга), -ан / -ань(здоровань), -яр (носяра), еtс. [14: 198-199]. 
3. Grammatical categories of number and case in the English language.

The Ukrainian language possesses the category of gender, apart from the mentioned ones, which is absent in English. Ukrainian category of gender can be regarded as lexico-grammatical one since not only grammatical features but also the semantic ones (that is a division according to sex, age) are taken into consideration: син - дочка. Besides in Ukrainian we have nouns of the so called common саse (спільний рід - трудяга, нечепура, плакса) which belong either to masculine or to feminine gender depending on the context.

Though both contrasted languages contain categories of number and case their opposemes, especially those of the category of case, differ considerably. In both languages different case grammemes are used in different functions. Ukrainian nominative case grammeme can be the subject, whereas an accusative case grammeme can be a direct object and only a nominative or an instrumental case grammemes are used in the function of predicative. English possessive case grammemes are used almost exclusively as attributes whereas common case grammemes perform functions of practically any part of a sentence.

4. Typical combinability. The English noun has left-hand combinability with articles, prepositions, adjectives, possessive pronouns (besides demonstrative pronouns, some indefinite and negative pronouns), other nouns, etc.; and right-hand connections with nouns (the so-called noun clusters), verbs.

Typical combinability of Ukrainian nouns differs. Their left-hand connections are with prepositions, adjectives, possessive pronouns (also demonstrative pronouns, some indefinite and negative pronouns). The Ukrainian noun does not form noun-clusters abounding in English and the right-hand connections of the Ukrainian noun are uniquely with verbs.

5. Typical syntactic function. The English noun performs the role of a subject, an object, a complement or a predicative, less frequently attribute or other parts of a sentence. Typical syntactic functions of the Ukrainian noun are largely similar apart from the fact that the Ukrainian noun does not function as an attribute. For a detailed contrastive analysis with the application of feature based tertium comparationis approach consider [3: 60-63].

Conclusions and Perspectives. Summarizing the presented views on the usage of tertium comparationis it is worth remembering the view initially suggested by Tomasz P. Krzeszowski that this fundamental concept continues to be misunderstood and underused in cross-language research. Present day contrastive studies comprise various platforms of inter-linguistic reference, predetermined by specific linguistic models which they apply and specific levels of analyses which they embrace. Different tertia comparationis are used and should be used for comparisons in phonology, lexicology and syntax and only in few of these studies they are explained explicitly enough.

To elucidate some disputable issues regarding the usage of tertium comparationis we consider worthy to apply the theoretical reasoning, suggested by professor Nadiya Andreichuk, that tertium comparationis should be viewed as an overall platform of reference which enables the comparison to be performed. It should be considered as a background of sameness and the sine qua non for any valid, understandable as well as systematic research of contrasts to be presented for their further study and application for various purposes (theoretical, practical, didactic, methodological etc.). While comparing and contrasting we should precede with the basic assumption that the objects to be compared have something in common, against which differences can be determined. The same objects turn out to be either similar or different depending on tertium comparationis or the platform of reference we apply.

Looking for possible tertia comparationis one should not limit oneself to only two largely discussed in theory types: formal correspondence and semantic equivalence. Two mentioned types of tertium comparationis are not the only ones that should be used in practice. Semantic equivalence and formal correspondence can be employed as tertia comparationis for specific types of contrastive studies (lexical and syntactic in particular). Contrastive studies based exclusively either on formal correspondence or those based on semantic equivalence are not free from difficulties. Formal similarity alone cannot serve as a tertium comparationis without being supported by semantic equivalence. Furthermore, comparison grounded on the formal criterion alone is not substantial, incomplete and in many cases can be misleading.

The substantiated choice of tertium comparationis helps to reveal the determining similarities and differences in the phenomena compared. Consequently various types of contrastive research patterns can be singled out, depending on the tertium comparationis chosen and the kind of equivalence used. Other / different types of contrastive studies such as phonological, pragmatic or quantitative should be based on other/different tertia comparationis which can be considered as a perspective research direction in modern Contrastive Linguistics.

\section{СПИСОК ВИКОРИСТАНИХ ДЖЕРЕЛ ТА ЛІТЕРАТУРИ}

1. Krzeszowski T. P. Contrasting Languages. The Scope of Contrastive Linguistics / Tomasz P. Krzeszowski. Berlin, New York : Mouton de Gruyter, 1990. - 290 p.

2. Кочерган М. П. Основи зіставного мовознавства : [підручник] / М. П. Кочерган. - К. : Академія, 2006. $424 \mathrm{c}$. 
3. Karamysheva I. D. Contrastive Grammar of English and Ukrainian Languages : Textbook; Third Edition, Revised / Iryna Karamysheva. - Vinnytsia : Nova Knyha Publishers, 2017. - 336 p.

4. Krzeszowski T. P. Early Contrastive Studies in England, 15th-18th Centuries / Tomasz P. Krzeszowski. - Gdańsk : Universytet Gdański, 1995. - 226 p.

5. Андрейчук H. I. Contrastive Linguistics = Контрастивна лінгвістика : [навч. посібник] / Н. І. Андрейчук. Львів : ЛНУ імені Івана Франка, 2015. - 343 с.

6. Whorf B. L. Language and Logic // Language, Thought and Reality. Selected writings of Benjamin Lee Whorf / Benjamin Lee Whorf ; ed. and introd. by Carroll J.B., foreword by Chase S. - Cambridge, Mass. : The MIT Press, 1956. - P. 233-245. (total 278 p.). - Possible mode of access: http://archive.org/stream/languagethoughtr00whor\#page/n7/ mode/2up.

7. Fries C. C. Teaching and learning English as a foreign language / Charles Fries. - Ann Arbor, MI : University of Michigan Press, 1945.

8. Lado R. Linguistics across Cultures. Applied Linguistics for Language Teachers / Robert Lado. - Ann Arbor : University of Michigan Press, 1957. - 141 p.

9. Жлуктенко Ю. О. Порівняльна граматика англійської та української мов : [посібник] / Ю. О. Жлуктенко. К. : Радянська школа, 1960. - 160 с

10. Жлуктенко Ю. О. Контрастивний аналіз як прийом мовного дослідження / Ю. О. Жлуктенко // Нариси 3 контрастивної лінгвістики. - К. : Наукова думка. - 1979. - С. 5-11.

11. Жлуктенко Ю. О. О некоторых вопросах контрастивного анализа языков / Ю. О. Жлуктенко // Вестник КГУ. - 1978. - Романо-германская филология. - № 12.

12. Жлуктенко Ю. О. Контрастивна лінгвістика : Проблеми і перспективи / Ю. О. Жлуктенко, В. Н. Бублик // Мовознавство. - 1976. - № 4. - С. 3-15.

13. Порівняльні дослідження з граматики англійської, української, російської мов / відп. ред. Ю. О. Жлуктенко. - К. : Наукова думка, 1981. - 353 с.

14. Корунець I. В. Порівняльна типологія англійської та української мов : [навч. посібник] (Korunets I. V. Contrastive Typology of the English and Ukrainian languages) / I. В. Корунець. - Вінниця : Нова книга, 2003. $464 \mathrm{c}$.

15. Левицький А. Е. Порівняльна граматика англійської та української мов : [підручник] / А. Е. Левицький. К. : Видавничо-поліграфічний центр "Київський університет", 2008. - 264 с.

16. Джеймс К. Контрастивный анализ / К. Джеймс // Новое в зарубежной лингвистике. - М. : Прогресс, 1989. Вып. XXV. - Контрастивная лингвистика. - С. 205-306.

17. Никель Г. Контрастивная лингвистика и обучение иностранным языкам / Г. Никель // Новое в зарубежной лингвистике. - М. : Прогресс, 1989. - Вып. XXV. Контрастивная лингвистика. - С. 350-365.

18. Немзер У. Проблемы и перспективы контрастивной лингвистики / У. Немзер // Новое в зарубежной лингвистике. - М. : Прогресс, 1989. - Вып. XXV. Контрастивная лингвистика. - С. 128-143.

19. Штернеманн Р. Введение в контрастивную лингвистику / Р. Штернеманн (рук.) и коллектив авторов // Новое в зарубежной лингвистике. - М. : Прогресс, 1989. - Вып. XXV. Контрастивная лингвистика. C. $145-150$

20. Chesterman A. "Interpreting the Meaning of Translation" Read at the Symposium "Translation - Interpretation Meaning", Held at the Helsinki Collegium for the Advanced Studies on January 27-29, 2005. - Mode of access : http://www.linguistics.fi/julkaisut/SKY2006_1/1FK60.1.1.CHESTERMAN.pdf.

\section{REFERENCES (TRANSLATED \& TRANSLITERATED)}

1. Krzeszowski T. P. Contrasting Languages. The Scope of Contrastive Linguistics / Tomasz P. Krzeszowski. Berlin, New York : Mouton de Gruyter, 1990. - 290 p.

2. Kocherhan M. P. Osnovy zistavnoho movoznavstva [Basics of Comparative Linguistics]: [pidruchnyk] / M. P. Kocherhan. - K. : Akademiya, 2006. - 424 s.

3. Karamysheva I. D. Contrastive Grammar of English and Ukrainian Languages; Third Edition, Revised / Iryna Karamysheva. - Vinnytsia : Nova Knyha Publishers, 2017. - 336 p.

4. Krzeszowski T. P. Early Contrastive Studies in England, 15th-18th Centuries / Tomasz P. Krzeszowski. - Gdańsk : Universytet Gdański, 1995. - 226 p.

5. Andreichuk N. I. Contrastive Linguistics $=$ Kontrastyvna linhvistyka [Contrastive Linguistics] : [navch. posibnyk] / N. Andreichuk. - L'viv : LNU imeni Ivana Franka, 2015. - 343 s.

6. Whorf B. L. Language and Logic // Language, Thought and Reality. Selected writings of Benjamin Lee Whorf / Benjamin Lee Whorf; ed. and introd. by Carroll J. B., foreword by Chase S. - Cambridge, Mass. : The MIT Press, 1956. - P. 233-245. (total 278 p.). - Possible mode of access : http://archive.org/stream/languagethoughtr00whor\#page/n7/ mode/2up.

7. Fries C. C. Teaching and learning English as a foreign language / Charles Fries. - Ann Arbor, MI : University of Michigan Press, 1945.

8. Lado R. Linguistics across Cultures. Applied Linguistics for Language Teachers / Robert Lado. - Ann Arbor : University of Michigan Press, 1957. - 141 p.

9. Zhluktenko Yu. O. Porivnyal'na hramatyka anhliis'koi ta ukrayins'koi mov [Comparative Grammar of English and Ukrainian Languages] : [posibnyk] / Yu. O. Zhluktenko. - K. : Radians'ka shkola, 1960. - $160 \mathrm{~s}$.

10. Zhluktenko Yu. O. Kontrastyvnyi analiz yak pryiom movnoho doslidzhennia [Contrastive Analysis as a Method of Language Research] / Yu. O. Zhluktenko // Narysy z kontrastyvnoi linhvistyky [Essays on Contrastive Linguistics]. - K. : Naukova dumka. - 1979. - S. 5-11. 
11. Zhluktenko Yu. O. O nekotorykh voprosakh kontrastivnogo analiza yazykov [On Some Issues of Contrastive Language Analysis] / Yu. O. Zhluktenko // Vestnik KGU [Bulletin of KSU]. - 1978. - Romano-germanskaia filologiia. - № 12.

12. Zhluktenko Yu. O. Kontrastyvna linhvistyka : Problemy i perspektyvy [Contrastive Linguistics: Problems and Prospects] / Yu. O. Zhluktenko // Movoznavstvo [Linguistics]. - 1976. - № 4. - S. 3-15.

13. Porivnyal'ni doslidzhennia $\mathrm{z}$ hramatyky anhliis'koi, ukrains'koi, rosiis'koi mov [Comparative Study of Grammar of English, Ukrainian, Russian Languages] / vidp. red. Yu. O. Zhluktenko. - K. : Naukova dumka, 1981. - 353 s.

14. Korunets I. V. Porivnyal'na typolohiia anhliis'koi ta ukrains'koi mov [Contrastive Typology of the English and Ukrainian languages] : [navch. posibnyk] / I. V. Korunets. - Vinnytsya : Nova knyha, 2003. - 464 s.

15. Levytskyi A. E. Porivnyal'na hramatyka anhliis'koi ta ukrains'koi mov [Comparative Grammar of English and Ukrainian Languages] : [pidruchnyk] / A. E. Levytskyi. - K. : Vydavnycho-polihrafichnyi tsentr "Kyivs'kyi universytet", 2008. - $264 \mathrm{~s}$.

16. Dzheyms K. Kontrastivnyi analiz [Contrastive Analysis] / K. Dzheyms // Novoie v zarubezhnoi lingvistike [New in Foreign Linguistics]. - M. : Progress, 1989. - Vyp. XXV. Kontrastivnaia lingvistika. - S. 205-306.

17. Nikel G. Kontrastivnaia lingvistika i obucheniie inostrannym yazykam [Contrastive Linguistics and Foreign Language Teaching] / G. Nikel // Novoie v zarubezhnoi lingvistike [New in Foreign Linguistics]. - M. : Progress, 1989. - Vyp. XXV. - Kontrastivnaia lingvistika. - S. 350-365.

18. Nemzer U. Problemy i perspektivy kontrastivnoi lingvistiki [Problems and Prospects of Contrastive Linguistics] / U. Nemzer // Novoie v zarubezhnoi lingvistike [New in Foreign Linguistics]. - M. : Progress, 1989. - Vyp. XXV. Kontrastivnaia lingvistika. - S. 128-143.

19. Shternemann R. Vvedeniie v kontrastivnuiu lingvistiku [Introduction to Contrastive Linguistics] / R. Shternemann (ruk.) i kollektiv avtorov // Novoie v zarubezhnoi lingvistike [New in Foreign Linguistics]. - M. : Progress, 1989. Vyp. XXV. Kontrastivnaia lingvistika. - S. 145-150.

20. Chesterman A. "Interpreting the Meaning of Translation" Read at the Symposium "Translation - Interpretation Meaning", Held at the Helsinki Collegium for the Advanced Studies on January 27-29, 2005. - Mode of access : http://www.linguistics.fi/julkaisut/SKY2006_1/1FK60.1.1.CHESTERMAN.pdf.

\section{Карамышева И. Д. Теrtium Сотратаtionis в современной контрастивной лингвистике (пересмотр подходов к обучению).}

В статье отражены основные дискуссионные моменты в области кросс-культурных языковых исследований. Определяется место современной контрастивной лингвистики среди смежных дисциплин. Представлены периоды развития контрастивистики, которые влияли на принципь и терминологический аппарат, выработанные в теоретических и прикладных сопоставительных студиях. Описаны подходы, применяемые украинскими авторами имеющихся современных учебных пособий, которые создают необходимый дидактический фон для усвоения теоретикометодологических основ, на которых зиждется современная контрастивная лингвистика.

Дискутируются подходы к пониманию и корректному применению tertium comparationis как общей платформы для сравнения, что дает возможность корректного анализа объекта исследования с иелью выявления его общих и отличительных признаков в сопоставляемых языках.

Ключевые слова: контрастивная лингвистика, контрастивний анализ, платформа для сравнения, tеtiuт comparationis, критерий для сравнения, эквивалентность.

\section{Карамищева І. Д. Tertium Cотранаtionis в сучасній контрастивній лінгвістиці (перегляд підходів до викладання).}

У статті висвітлено основні дискусійні моменти у царині крос-культурних мовних досліджень. Окреслюється місче сучасної контрастивної лінгвістики серед суміжних дисциплін. Представлені періоди розвитку контрастивних учень, які впливали на термінологічний апарат та приниипи, випрацювані у теоретичних та прикладних контрастивних студіях. Описано підходи, застосовані украӥнськими авторами сучасних посібників, які створюють необхідне дидактичне тло для розуміння теоретико-методологічних основ, на яких трунтується сучасна контрастивна лінгвістика.

Дискутуються підходи до розуміння та коректного застосування tertium comparationis як спільної платформи для порівняння, щзо уможливлює коректний аналіз об'єкту дослідження з метою виявлення його спільних та відмінних ознак у зіставлювальних мовах.

Ключові слова: контрастивна лінгвістика, контрастивний аналіз, платформа для зіставлення, tеtiuт coтparationis, критерій для порівняння / зіставлення, еквівалентність. 